\title{
Endogenous income distribution in the Bhaduri-Marglin model
}

\author{
Bernhard Schütz*
}

\begin{abstract}
The results of the Bhaduri-Marglin model build on the assumption of an exogenous profit share. The present paper examines critically the robustness of these results by asking how its results change if we take the endogeneity of the profit share into account. In doing so, the constituents of the latter (labor productivity and the real wage rate) are treated as endogenous. The paper finds that the conditions for wage-and profit-led regimes only change when we assume increases in the real wage rate to be followed by very strong labor rationalization. Furthermore, the paper shows how these additional channels can increase or decrease the profitled/wage-led character of a regime and how they may even become a source of instability.
\end{abstract}

JEL classifications: EI2, E2I, E22, E25

Keywords: Income distribution, wage-led/profit-led demand regimes, labor rationalization

* University of Linz. I am indebted to Martin Riese. For helpful comments I would like to thank Amit Bhaduri, Eckhard Hein, Michael Landesmann, Engelbert Stockhammer, the participants of the 2009 Conference of the Research Network of Macroeconomics and Macroeconomic Policies (FMM) as well as two anonymous referees. Remaining errors are of course mine. Financial support from the Fonds zur Förderung der wissenschaftlichen Forschung (FWF), Vienna, Project-No. P18419-G05 is gratefully acknowledged.

Correspondence Address:

Berhard Schürz, University of Linz, Department of Economics, Altenbergerstraße 69, A-4040 Linz, Austria, e-mail: bernhard.schuetz@jku.at.

Received I6 March 20I2, accepted I2 May 2012

(C) INTERVENTION 9 (2), 2012, 309-320 


\section{Introduction}

Since the Bhaduri-Marglin model has been published in 1990 it has had a large influence on Post-Keynesian thinking and has inspired much empirical research. ${ }^{\mathrm{I}}$ The reason for its impact was that compared to the classical closed economy Kaleckian model, where redistributing income from profits to wages always led to an increase in aggregate demand, it also allowed for a negative relationship by accounting for a negative effect on investment. Bhaduri and Marglin (1990) received as a result two types of demand regimes for the short period: exhilarationist (lower real wages having a positive effect on demand) and stagnationist (lower real wages having a negative effect on demand). Today the two original terms have been replaced by the somewhat simpler terms profit-led (instead of exhilarationist) and wage-led (instead of stagnationist) demand regimes.

Though their results were quite influential, they built on the simplifying assumption of an exogenous profit share. The current paper relaxes this assumption, asking whether Bhaduri's and Marglin's original results are robust to these changes and, in case they are not, how they change as a consequence. More specifically, we allow for (I) a feedback mechanism of capacity utilization on labor productivity, (2) more expensive labor leading to labor rationalization and (3) real wages to react to changes in capacity utilization.

This is done by drawing on concepts that have already been employed in a number of similar models. ${ }^{2}$ The contribution of this paper is therefore not the specific type of the proposed labor productivity or wage bargaining functions, but will instead be the assessment of their implications for the original Bhaduri-Marglin framework.

\section{The Bhaduri-Marglin model}

In Bhaduri and Marglin (1990) prices are set as a mark-up on unit costs according to

$$
p=(1+m)\left(\frac{w}{\lambda}+E p_{f} \mu\right)
$$

where $m$ denotes the mark-up, $w$ the nominal wage rate, $\lambda$ labor productivity, $E$ the nominal exchange rate defined as units of domestic currency per unit of foreign currency, $p_{f}$ the foreign price level and $\mu$ the proportion of imported intermediate goods used per unit of

I See Bowles/Boyer (1995), Gordon (1995), Stockhammer/Onaran (2004), Onaran/Stockhammer (2005), Naastepad (2006), Naastepad/Storm (2006), Hein/Vogel (2008), Stockhammer/Ederer (2008), Stockhammer et al. (2009), Stockhammer/Stehrer (2009), Hein/Tarassow (20I0) and Storm/Naastepad (20I2).

2 Models accounting for endogenous labor productivity can e.g. be found in Rowthorn (1982), Taylor (199I), Lavoie (1992), Cassetti (2003), Lima (2004), Hein (2004), Barbosa-Filho/Taylor (2006), Naastepad (2006), Hein/Tarassow (20I0), Naastepad/Storm (20I0) and Storm/Naastepad (20I2). Endogenous determinations of the real wage rate can e.g. be found in Lavoie (1992), Cassetti (2003), Lima (2004), Taylor (2004), Barbosa-Filho/Taylor (2006), Raghavendra (2006) and Julius (2009). 
output. From (1) the share of profit income in total income, i.e. the profit share $(h)$, can be written as

$$
h=\frac{\Pi}{\Pi+\omega L}=\frac{m\left(\frac{\omega}{\lambda}+e \mu\right)}{\frac{\omega}{\lambda}+m\left(\frac{\omega}{\lambda}+e \mu\right)},
$$

where $L$ stands for total employment, $e=p_{f} E / p$ for the real exchange rate and $\omega$ for the real wage rate.

It is assumed that capitalists save a constant fraction $(s)$ of their income (consisting of total profits $\Pi$ ), while workers consume all of their income. Normalizing all relevant variables by full capacity output $Y^{*}$ and setting $Y^{*}=1$ allows us to write total saving as

$$
S=s \frac{\Pi}{Y} \frac{Y}{Y^{*}} Y^{*}=s h z
$$

where $z=Y / Y^{*}$ is the level of capacity utilization. Investment depends positively on the rate of capacity utilization and the profit share:

$$
I=I(h, z), \quad \frac{\partial I}{\partial h}>0 \quad \frac{\partial I}{\partial z}>0 .
$$

Net exports depend positively on the real exchange rate and negatively on the rate of capacity utilization (see Bhaduri/Marglin 1990, Blecker 1999 and 2002, Hein/Vogel 2008):

$$
N X=N X(e, z), \quad \frac{\partial N X}{\partial e}>0 \quad \frac{\partial N X}{\partial z}<0 .
$$

In equilibrium, aggregate saving must be equal to investment and net exports:

$$
\operatorname{sh} z=I(h, z)+N X(e, z) .
$$

At this stage we assume the real wage rate to be exogenously given $\left(\omega=\omega_{0}\right)$. By applying total differentiation we can solve for $d z / d \omega_{0}:^{3}$

$$
\frac{d z}{d \omega_{0}}=\frac{A}{B},
$$

3 Applying total differentiation to equation (1) and (2) and using $d e=-p_{f} E / p^{2} d p$ and $d w=$ $p d \omega+\omega d p$ yields the reactions of the profit share and the real exchange rate to a change in the real wage rate:

$$
d h=-\frac{\frac{m}{\lambda}\left(\frac{\omega}{\lambda}+e \mu\right)}{\left[\frac{\omega}{\lambda}+m\left(\frac{\omega}{\lambda}+e \mu\right)\right]^{2}} d \omega, \quad d e=-\frac{1}{\lambda \mu} d \omega .
$$

Inserting into the total differential of (6) yields equation (7). 
where

$$
\begin{aligned}
& A=\left(s z-\frac{\partial I}{\partial h}\right) \psi_{1}-\frac{\partial N X}{\partial e} \psi_{2}, \\
& B=s h-\frac{\partial N X}{\partial z}-\frac{\partial I}{\partial z}, \\
& \psi_{1}=\frac{\frac{m}{\lambda}\left(\frac{\omega}{\lambda}+e \mu\right)}{\left[\frac{\omega}{\lambda}+m\left(\frac{\omega}{\lambda}+e \mu\right)\right]^{2}} \quad \psi_{2}=(\lambda \mu)^{-1} .
\end{aligned}
$$

In this section we try to stick as close as possible to the original representation of the model. Notwithstanding, we have to slightly depart from it at this point: While Bhaduri and Marglin (I990) solved for $d z / d h$ in (7), we choose to solve for $d z / d \omega_{0}$ instead. The reason is that in the next section we treat the profit share as an endogenous variable, meaning that we have to solve for $d z / d \omega_{0}$ then (otherwise we would again abstract from endogenous movements in the profit share). In order to facilitate the comparison between the original result and the result gained in the next section we change the representation already at this point (with labor productivity assumed constant it does not change the substance).

According to the Keynesian stability condition the reactions of saving and net exports to an increase in capacity utilization must exceed the reaction of investment, which requires $B>0$ and puts a positive sign on the denominator. With a positive denominator the sign of $d z / d \omega_{0}$ is determined by the numerator, which has basically two components: a domestic and a foreign one. An increase in real wages leads to a decrease in the profit share. Since the propensity to consume out of wage income is higher, this leads to a rise in consumption by $s z$. However, a lower profit share also decreases investment $(\partial I / \partial h)$. Whether domestic demand increases depends on which of these effects dominates. Furthermore there is also an effect on net exports: A rise in domestic wages increases prices and decreases net exports $(\partial N X / \partial e)$. It follows that domestic output decreases as a result of higher real wages, i.e. demand is profit-led, when $A<0$. When $\mathrm{A}>0$ demand is wage-led.

At this stage we may ask whether these results would change if we drop the assumption of an exogenous profit share, which is what we do in the next section.

\section{Endogenous income distribution: utilization effects, labor rationalization and wage bargaining}

There are several growth models that take into account that more expensive labor may increase labor saving technological progress (see e.g. Taylor I991, Lavoie I992, Cassetti 2003, Lima 2004, Barbosa-Filho/Taylor 2006, Naastepad 2006, Hein/Tarassow 20I0, Naastepad/Storm 
2010 and Storm/Naastepad 20I2), a concept which goes back to Marx (I867) and Hicks (I932). Whether this is relevant for the model at hand (and should therefore be included) depends crucially on the underlying time-frame. The Bhaduri-Marglin model we are using is a model for the short period (which is the period where capacity can be assumed constant; see King 2008), which becomes obvious from the assumption of a constant $Y^{*}$. Such a setting rules out technological progress that is attached to additional capital. However, does this mean that firms cannot react at all to cost increases in the short period? Rather not. A firm facing higher costs can, even in the short period, cut costs by restructuring the production process, for example by dismissing workers and dividing the same number of tasks among fewer people. Increasing working hours, reports of mental overload and burnout in developed economies are a clear sign that the workload per employee has indeed increased. Furthermore, the rising importance of foreign markets as a source of demand for one's products and the prevalence of export-oriented growth strategies - Germany being a very prominent example - should have contributed to an increasing sensitivity of certain industries with respect to labor costs. ${ }^{4}$ For our model this implies $\partial \lambda / \partial \omega>0$.

Another concept that can be frequently found in growth models (see e.g. Cassetti 2003, Hein 2004, Naastepad 2006, Hein/Tarassow 20Io, Naastepad/Storm 2oIo and Storm/ Naastepad 20I2) is called the Kaldor-Verdoorn relation (Kaldor 1966), which basically says that output growth has a positive impact on productivity growth because growing markets allow for increasing division of labor and thereby create dynamic economies of scale. The core of this concept is related to a structural change in the production process and therefore applies to the long period. For the short period a different concept, which can be found in Rowthorn (1982) and Lavoie (1992), seems more relevant: Labor productivity increases with the rate of capacity utilization as the employment of some workers depends less on actual output than the employment of others. While employment of those workers directly engaged in the production process (blue collar workers) is rather elastic with respect to actual output, employment of white collar workers (lawyers, accountants etc.) is rather inelastic and depends to a great deal on the level of potential (rather than actual) output. When capacity utilization rises, total employment rises less than output and we observe a rise in aggregate labor productivity. For our model this results in the following labor productivity function:

$$
\lambda=\lambda(z, \omega), \quad \frac{\partial \lambda}{\partial z}>0 \quad \frac{\partial \lambda}{\partial \omega}>0 .
$$

Real wages depend on nominal wage bargaining as well as price setting by firms. A higher rate of capacity utilization will typically improve the wage bargaining position of workers, leading to an increase in nominal wages. In an open economy with imported intermediate

4 Such a strategy may even cause labor rationalization in the case of non-increasing wages when firms deem the actual level of labor cost as too high for gaining international market shares. In this case, not the change in the wage level would cause labor rationalization, but a change in the parameter of the labor productivity function. 
goods this will also lead to an increase in real wages. ${ }^{5}$ In order to keep the model as illustrative as possible we abstain from a detailed modeling of the wage bargaining process as it can be found in other models (see e.g. Lavoie 1992, Cassetti 2003, Lima 2004 and Julius 2009). Rather we will include a very simple relation capturing the empirically observed outcome of this rather complex bargaining process, which is a pro-cyclical real wage rate (see Raghavendra 2006 and Swanson 2007):

$$
\omega=\omega_{0}+\omega_{1} z, \quad \omega_{0}, \omega_{1}>0
$$

Here $\omega_{0}$ denotes the institutionally determined exogenous component of the real wage rate whereas $\omega_{1}$ summarizes endogenous influences. Now let us again solve for $d z / d \omega_{0}$ :

$$
\frac{d z}{d \omega_{0}}=\frac{A\left(1-\varepsilon_{\lambda, \omega}\right)}{B+A H}
$$

where

$$
\begin{aligned}
& A=\left(s z-\frac{\partial I}{\partial h}\right) \psi_{1}-\frac{\partial N X}{\partial e} \psi_{2}, \\
& B=s h-\frac{\partial N X}{\partial z}-\frac{\partial I}{\partial z}, \\
& H=\frac{\omega}{z}\left[\varepsilon_{\lambda, z}-\varepsilon_{\omega, z}\left(1-\varepsilon_{\lambda, \omega}\right)\right], \\
& \varepsilon_{\lambda, \omega}=\frac{\omega}{\lambda} \frac{\partial \lambda}{\partial \omega}, \quad \varepsilon_{\lambda, z}=\frac{z}{\lambda} \frac{\partial \lambda}{\partial z}, \quad \varepsilon_{\omega, z}=\frac{z}{\omega} \omega_{1} .
\end{aligned}
$$

$\varepsilon_{\lambda, \omega}$ denotes the elasticity of productivity with respect to the real wage rate and $\varepsilon_{\lambda, z}$ and $\varepsilon_{\omega, z}$ are the elasticities of productivity and the real wage rate with respect to capacity utilization. We can see that the numerator and the denominator are affected by these changes: The former is multiplied by $\left(1-\varepsilon_{\lambda, \omega}\right)$, while the additional term $A H$ has been added to the latter.

\section{The denominator-Multiplier effects and instability}

A necessary condition for stability is still that savings and net exports react more to an increase in capacity utilization than investment. In our extended model this is satisfied when $B+A H>0$. The standard Keynesian stability condition assumes $B>0$, which means for our case that stability, i.e. the positivity of the denominator, is questioned when $A H<0$, which happens either with $A>0$ and $H<0$ or $A<0$ and $H>0$. See on this issue also Bhaduri (2008),

5 In an open economy a rise in nominal wages will (even with a constant mark-up) lead to a less than one to one increase in prices, since the price of the second production input - imported intermediate goods - does not increase (see equation 1). Note that we also assume the nominal exchange rate to be fixed. 
who discusses out of equilibrium behavior in a dynamic system with an endogenous profit share. His general results concerning the stability of such a system can also be applied to the special case at hand. In the denominator, $B$ contains the reactions of $S, I$ and $N X$ to changes in capacity utilization when we hold the profit share constant. In the original model $B>0$ guaranteed that an expansion creates enough demand leakage (i.e. saving and imports) so that it eventually stops at a new equilibrium value of capacity utilization. In the extended model, changes in income distribution have to be considered additionally. Stability is not questioned when $A$ and $H$ have the same sign, since this would only make the denominator more positive. The model may, however, display instability when these two terms have opposite signs.

Before we proceed, let us take a closer look at $H$. This term gives us the reaction of the profit share to a change in capacity utilization. If productivity gains due to a higher utilization of production capacity $\left(\varepsilon_{\lambda, z}\right)$ exceed (pro-cyclical) movements in the real wage rate $\left(\varepsilon_{\omega, z}\right)$ (minus possible labor rationalization effects $\left(\varepsilon_{\lambda, \omega}\right)$ that this may cause), then $H>$ 0 . In this case a rise in capacity utilization leads to a higher profit share, which would further increase capacity utilization in a profit-led regime $(A<0)$ and decrease capacity utilization in a wage-led regime $(A>0)$. In the first case these endogenous changes in the profit share may cause instability when they are sufficiently large, i.e. $|A H|>B$ : Increases in capacity utilization cause a rise in the profit share, which further increases demand, leading to a rise in capacity utilization again and so on.

Contrariwise, when the real wage rate shows a rather strong pro-cyclical pattern, such that its reaction exceeds the reaction of labor productivity, then $H<0$. In this case a rise in capacity utilization leads to a fall in the profit share, which further increases capacity utilization in a wage-led regime and decrease capacity utilization in a profit-led regime, causing instability in the first case when these changes are sufficiently large $(|A H|>B)$ : A rise in capacity utilization leads to a decrease in the profit share, which further increases demand, leading to a further reduction in the profit share and so on.

We can summarize this discussion by saying that: $H>0$ increases the profit-led character or decreases the wage-led character of a demand regime, while $H<0$ increases the wageled character and decreases the profit-led character of a demand regime. See also Taylor (2004, Ch. 7) who illustrates how distributional changes affect the impact of expansionary economic policies.

\section{The numerator - Labor rationalization effects}

Now let us turn to the numerator, where we observe the second impact of labor rationalization $\left(\varepsilon_{\lambda, \omega}\right)$ within the model. As long as this elasticity is smaller than unity (which seems sensible), labor rationalization only decreases the wage-led/profit-led character of a demand regime but does not change its wage-led/profit-led nature. Therefore, the sign of $A$ still determines the nature of the demand regime and the results of Bhaduri and Marglin turn out to be quite robust in this respect. Hypothetically, if $\varepsilon_{\lambda, \omega}>1$, an increase in the real wage rate would lead to so much labor rationalization to cause an increase in the profit share. In this case we 
would observe the paradoxical result that a decrease in the profitshare would increase demand $(A>0)$, but an increase in the real wage rate would not. In other words, such a demand regime may be wage-led (increasing workers income share would increase demand), but not wage-rate-led (increasing the wage rate decreases demand). Naastepad (2006) receives the same results for the impact of labor rationalization (though she calls it induced technological progress) in a slightly different framework. ${ }^{6}$ However, from a real world perspective this scenario seems, at least within the short period, rather unlikely. Naastepad (2006) estimates this elasticity to be 0.52 for the Netherlands. Hein's and Tarassow's (20I0) estimates for various countries vary between 0.25 (UK) and 0.67 (Austria) $^{7}$ and Storm and Naastepad (2012) find an elasticity of 0.29 for a cross section of 20 OECD countries. Nevertheless these estimates indicate that this channel is probably non-negligible.

\section{Aggregate impact}

We have seen so far that changes in the denominator may increase or decrease the profitled/wage-led nature of a demand regime and can potentially lead to instability. Furthermore we found that the original condition for a wage-led demand regime $(A>0)$ changes only under the assumption of a very high degree of labor rationalization. We can now analyze how the size of $d z / d \omega_{0}$ changes compared to the original model: Depending on the signs of $A$ and $H$ the denominator can either increase or decrease. In a wage-led regime $(A>0)$ with a pro-cyclical profit share $(H>0)$ the denominator increases. If we assume $0<\varepsilon_{\lambda, \omega}<1$, this regime would become less wage-led (numerator decreases, denominator increases). The economic sense behind this is that labor rationalization and pro-cyclical changes in the profit share dampen the increase in demand. If the profit share behaved counter-cyclically $(H<0)$, the direction of change would be ambiguous (numerator and denominator decrease): Labor rationalization dampens the positive effect of higher real wages, but counter-cyclical movements in the profit share fuel demand. See also Figure I.

In the profit-led case $(A<0)$ with a pro-cyclical profit share $(H>0)$ the denominator decreases. Since the absolute value of the numerator is smaller than in the original model, the profit-led character of the regime may increase or decrease: Labor rationalization decreases the profit-led character (firms can fight a decrease in the profit share through labor rationalization), but pro-cyclical changes in the profit share work to increase the downturn. If the profit share behaved counter-cyclically $(H<0)$, the demand regime would become clearly less profit-led (numerator decreases, denominator increases): Labor rationalization as well as counter-cyclical changes in the profit share (when demand decreases the profit share tends to increase) dampen the negative effect of a higher real wage rate. See also Figure 2.

6 See also Naastepad/Storm (20IO) and Storm/Naastepad (20I2) who extend this model to analyze the impact of labor market deregulation on growth.

7 Estimated elasticities for the US, Germany, France and the Netherlands lie between 0.3I and 0.36 . 


\section{Figure I}
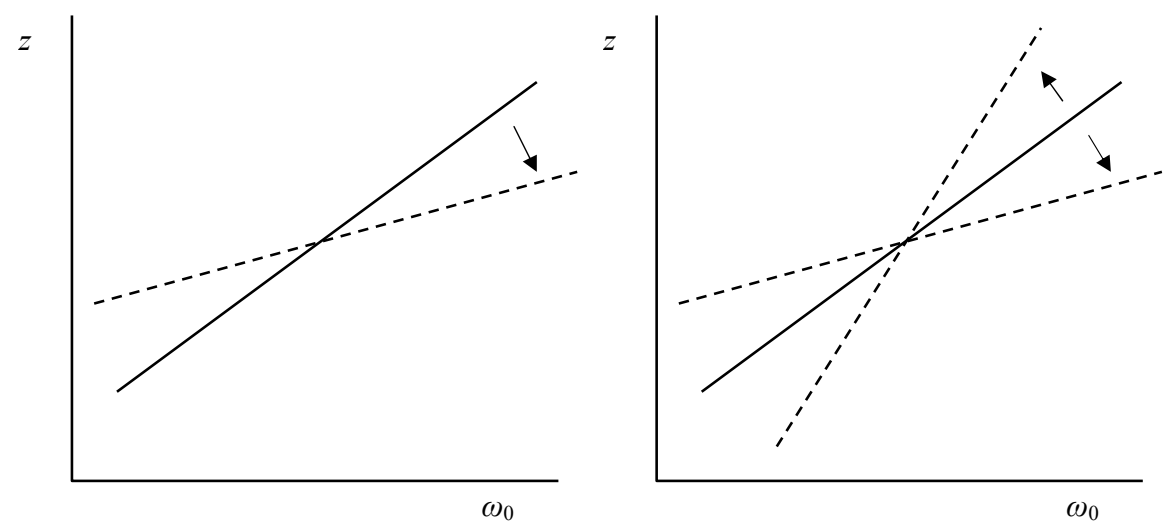

Note: With a pro-cyclical profit share $(H>0)$, the wage-led character of the demand regime decreases (left), whereas with a counter-cyclical profit share $(H<0)$ the direction of change is ambiguous (right).

Figure 2
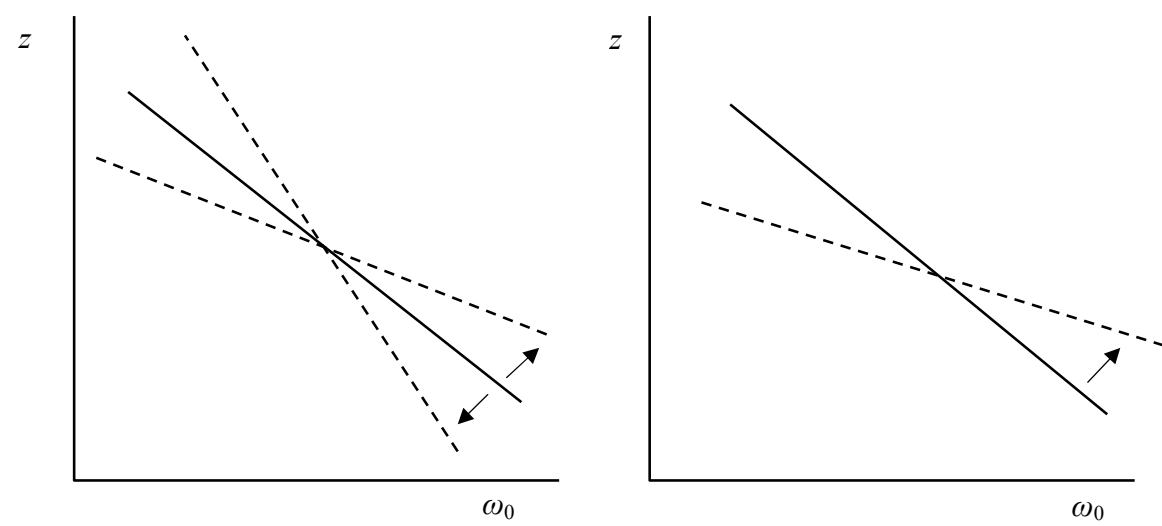

Note: With a pro-cyclical profit share $(H>0)$, the profit-led character of the demand regime may increase or decrease (left), whereas with a counter-cyclical profit share $(H<0)$ it will decrease (right). 


\section{Conclusions}

This paper questioned the assumption of exogenous income distribution within the BhaduriMarglin model. Thereby it allowed for the possibility of labor rationalization as well as for positive effects on productivity coming from higher degrees of capacity utilization. Furthermore it accounted for pro-cyclical behavior of the real wage rate. It turned out that the original conditions of Bhaduri and Marglin for profit-led/wage-led regimes are quite robust to these modifications: They would only change if we assumed a very high degree of labor rationalization, which is according to empirical studies unlikely to be observed (at least within the short period). In this respect the paper confirms the results gained by Naastepad (2006) for labor rationalization in a slightly different framework. However, what does change when we account for an endogenous profit share is the magnitude of profitled/wage-led regimes. The paper identified the conditions under which the original model overestimates the size of profit-led/wage-led regimes: In case of a pro-cyclical profit share, wage-led demand regimes become less wage-led, because labor rationalization and cyclical increases in the profit share dampen the rise in demand. A profit-led demand regime becomes less profit-led when the profit share reacts counter-cyclically. Here labor rationalization and a rising profit share (due to lower capacity utilization) dampen the fall in demand initially caused by a rise in the real wage rate. The direction of change is ambiguous for wage-led demand regimes under a counter-cyclical profit share and profit-led demand regimes under a pro-cyclical profit share. Possible scenarios in which instability can arise through these changes were also discussed.

\section{References}

Barbosa-Filho, N.H., Taylor, L. (2006): Distributive and demand cycles in the US economy A structuralist Goodwin model, in: Metroeconomica, 57(3), 389-4II.

Bhaduri, A. (2008): On the dynamics of profit-led and wage-led growth, in: Cambridge Journal of Economics, 32(I), $147-160$.

Bhaduri, A., Marglin, S. (1990): Unemployment and the real wage: the economic basis of contesting political ideologies, in: Cambridge Journal of Economics, I4(4), 375-393.

Blecker, R.A. (1999): Kaleckian macro models for open economies, in: Deprez, J. (ed.), Foundations of International Economics: Post Keynesian Perspectives, New York, London: Routledge, II6-I49.

Blecker, R.A. (2002): Distribution, demand and growth in neo-Kaleckian macro models, in: Setterfield, M. (ed.), The Economics of Demand-Led Growth - Challenging the SupplySide Vision of the Long Run, Cheltenham: Edward Elgar, I29-I52.

Bowles, S., Boyer, R. (1995): Wages, aggregate demand, and employment in an open economy: An empirical investigation, in: Epstein, G.A., Gintis, H.M. (eds.), Macroeconomic Policy after the Conservative Era. Studies in Investment, Saving and Finance, Cambridge: Cambridge University Press, I43-17I. 
Cassetti, M. (2003): Bargaining power, effective demand and technical progress: a Kaleckian model of growth, in: Cambridge Journal of Economics, 27(3), 449-464.

Gordon, D.M. (1995): Growth, distribution, and the rules of the game: social structuralist macro foundations for a democratic economic policy, in: Epstein G.A., Gintis, H.M. (eds.), Macroeconomic policy after the conservative era. Studies in investment, saving and finance, Cambridge: Cambridge University Press, 355-383.

Hein, E. (2004): Verteilung und Wachstum, Marburg: Metropolis.

Hein, E., Tarassow A. (20IO): Distribution, aggregate demand and productivity growth - theory and empirical results for six OECD countries based on a post-Kaleckian model, in: Cambridge Journal of Economics, 34(4), 727-754.

Hein, E., Vogel, L. (2008): Distribution and growth reconsidered: Empirical results for six OECD countries, in: Cambridge Journal of Economics, 32(3), 479-5II.

Hicks, J.R. (1966 [1932]): The Theory of Wages, Basingstoke: Macmillan.

Julius, A.J. (2009): The wage-wage-...-wage-profit relation in a multisector bargaining economy, in: Metroeconomica, 60(3), 537-559.

Kaldor, N. (1966): Causes of the Slow Rate of Economic Growth of the United Kingdom, Cambridge: Cambridge University Press.

King, J.E. (2008): Heterodox macroeconomics: What, exactly, are we against?, in: Wray, L.R., Forstater, M. (eds.), Keynes and Macroeconomics after 70 years. Critical Assessments of the General Theory, Cheltenham, Northampton: Edward Elgar, 3-I9.

Lavoie, M. (1992): Foundations of Post-Keynesian Economic Analysis, Aldershot: Edward Elgar.

Lima, G.T. (2004): Endogenous technological innovation, capital accumulation and distributional dynamics, in: Metroeconomica, 55(4), 386-408.

Marx, K. (1977 [1867]): Capital-A Critique of Political Economy, London: Lawrence \& Wishart.

Naastepad, C.W.M. (2006): Technology, demand and distribution: a cumulative growth model with an application to the Dutch productivity growth slowdown, in: Cambridge Journal of Economics, 30(3), 403-434.

Naastepad, C.W.M., Storm, S. (2006): OECD demand regimes (1960-2000), in: Journal of Post Keynesian Economics, 29(2), 21I-246.

Naastepad, C.W.M., Storm, S. (20I0): Feasible egalitarianism: demand-led growth, labour and technology, in: Setterfield, M. (ed.), Handbook of Alternative Theories of Economic Growth, Cheltenham, Northampton: Edward Elgar, 3II-330.

Onaran, O., Stockhammer, E. (2005): Two different export-oriented growth strategies: Accumulation and distribution in Turkey and South Korea, in: Emerging Markets Finance and Trade, 4I(I), 65-89.

Raghavendra, S. (2006): Limits to investment exhilarationism, in: Journal of Economics, 87(3), $257-280$.

Rowthorn, B. (1982): Demand, real wages and economic growth, in: Studi economici, 18, 3-53.

Stockhammer, E., Ederer, S. (2008): Demand effects of the falling wage share in Austria, in: Empirica, 35(5), 48I-502. 
Stockhammer, E., Onaran, O. (2004): Accumulation, distribution and employment: a structural VAR approach to a Kaleckian macro model, in: Structural Change and Economic Dynamics, I5(4), 42I-447.

Stockhammer, E., Onaran, O., Ederer, S. (2009): Functional income distribution and aggregate demand in the Euro area, in: Cambridge Journal of Economics, 33(I), I39-I59.

Stockhammer, E., Stehrer, R. (2009): Goodwin or Kalecki in demand? Functional income distribution and aggregate demand in the short run, PERI Working Paper No. 203, in the meantime published in: Review of Radical Political Economics, 43(4), 20II, 506-522.

Storm, S., Naastepad, C.W.M. (2012): Macroeconomics Beyond the NAIRU, Cambridge/Mass., London: Harvard University Press.

Swanson, E.T. (2007): Real wage cyclicality in the PSID, Federal Reserve Bank of San Francisco Working Paper 2007-15.

Taylor, L. (I99I): Income Distribution, Inflation, and Growth - Lectures on Structuralist Macroeconomic Theory, Cambridge/Mass., London: MIT Press.

Taylor, L. (2004): Reconstructing Macroeconomics, Cambridge/Mass., London: Harvard University Press. 